\title{
Editorial
}

\section{Engolindo pedras e outras coisas}

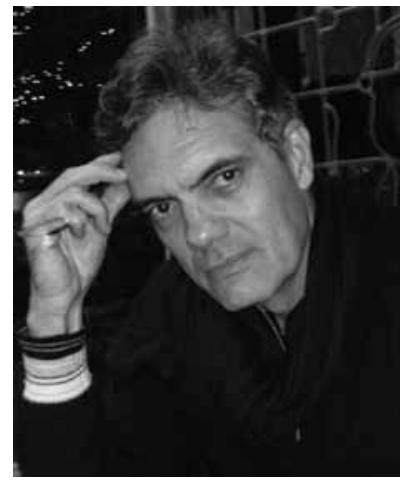

Marco Antonio Guimaráes da Silva

Interrompo a revisão que faço do que já escrevi do meu quinto romance para atender a um telefonema do editor executivo da revista Fisioterapia Brasil. Com seu acento pronunciadamente francês, ele me cobra o editorial.

Já há algum tempo não escrevo para a revista, e, para fazê-lo novamente, preciso tomar alguns cuidados; afinal, como escritor ficcionista, sou escravo de minhas próprias mentiras, mas aqui não me é permitido inventar histórias, contando verdades que não são verdadeiras.

Aqui não poderei ceder à força da ficção e deixar que a imaginação voe alto. Tampouco poderei, como faço em meus livros, exercitar a minha especulação silenciosa e egoisticamente individual, ferramenta imprescindível a qualquer escritor.

Também não terei tempo de escrever através da linha do tempo; o prazo que me foi dado não vai permitir, caso haja algum arrependimento do tipo querer voltar atrás para reescrever alguma coisa, seja para buscar uma sonoridade melhor para uma ou outra palavra do texto, seja para mudar de opinião, ou até mesmo - como dizia Clarice Lispector para impedir que as palavras esmaguem as entrelinhas. Porque se fizer isso, volto atrás e conserto as coisas. Esse talvez seja o maior instrumento que um escritor possui: ser senhor absoluto do tempo, retornar nesse tempo e ter o poder de desdizer amanhã o que disser hoje.

Mas aqui, nada de ficçáo. Já recebi indultos mais do que suficientes por parte da editoria executiva da revista, que me tem permitido escrever crônicas que fogem do objeto da revista e, ousadamente, à luz de pobres conceitos filosóficos e antropológicos, analisar a conduta de nossa sociedade, sociedade essa cujo comportamento nos oferece material suficiente para escrever uma centena ou talvez, para os mais profícuos, milhares de livros.

Já que falamos de tempo (me perdoem se volto a fazer uma digressão), aproveitarei a mitologia para fazer a minha leitura sobre a eleição de um senhor para a presidência do Senado, que a minha memória, muito seletiva, recusa-se a lembrar, e que eu, por comodidade, também não me esforço para descobrir, apesar das facilidades oferecidas pelo Google.

Conta a história que Cronos, rei dos Titãs, ao saber que um de seus filhos o mataria, resolvera engoli-los tâo logo nasciam. Zeia, sua mulher, cansada de ver o marido exterminar seus filhos, resolve enganá-lo, envolvendo uma pedra na manta do seu sexto filho, Zeus. Ele cresce e resolve vingar os irmáos, combate e vence Cronos, reinando supremo em todo o Universo.

Pois bem, analogias à parte e guardadas as devidas proporçôes, soube que esse senhor engoliu as milhares de assinaturas feitas para evitar a sua posse, sem dar sinais de que lhe pudessem causar qualquer tipo de distúrbio digestivo. Engoliu-as e sorriu, talvez porque soubesse que a lealdade de seus pares e subordinados não o trairia. Engolia também, naquele momento, a democracia, paradoxalmente pensando que os milhares de votos que recebera de seus incautos eleitores o credenciavam a tomar tal atitude. Incautos eleitores que, por sinal, são em número muito maior do que podemos imaginar, a julgar pela quantidade de congressistas atrelados às barras da lei que elegeram em outras instâncias.

Oxalá apareça uma Zeia da contemporaneidade, que consiga enganá-los e que consiga igualmente fazê-los engolir algo que os faça vomitar toda e qualquer vontade de se dedicar à vida pública. 